\title{
Hukuman Kebiri Kimia Bagi Pelaku Kekerasan Seksual Terhadap Anak Perspektif Fiqh Siyasah
}

\author{
Lukman Arake \\ Fakultas Syariah dan Hukum Islam, Institut Agama Islam Negeri Bone \\ Jl.Hos Cokro Aminoto, Watampone, Bone, Sulawesi Selatan, Indonesia \\ E-mail: fawwazlukman@gmail.com
}

\begin{abstract}
Responding to the high number of sexual violence against children, President Jokowi enacted the Regulation of Child Protection which in regulated chemical castration punishment as an additional penalty for perpetrators of sexual violence. However, a few years after the enactment, case of sexual violence against children remained high, but in fact there were no perpetrators of sexual violence that were castrated with chemicals. Because, the competence to do the castration chemistry by profession of doctor, but the Indonesian Doctors Association (IDI) refused to become the executor of castration chemistry, for reason of a humanity and violate a medical oath. Based on it, a chemical castration need to be explored in the perspective of Fiqh Siyasah. This research is a socioyuridical study, which relies on qualitative data, so to describe the castration punishment in Siyasah Fiqh perspective, the author used two approaches, that was the statutory approach and conceptual approach. The result of the research show that, normalizing chemical castration as an additional type of penalty for perpetrators of sexual violence is based on the consideration that (i) sexual violence against children is a very dangerous crime because this crime did not appear to the surface, (ii) made many victims accompanied with a long trauma, (iii) can even encourage victims to do suicide. (iv) In another, the perpetrators were not only Indonesian citizen, but foreigner who came to Indonesia in the guise of tourists and had a desire to look for a victim. However, out of these consideration, in the perspective of fiqh siyasah, based on the agreement of the cleric the application of chemical castration to perpetrator of sexual violence is unlawful. But the perpetrator can be convited to death, if the act is done repeatedly.
\end{abstract}

Keywords : Castration Chemistry ; Sexual Violence ; Fiqh Siyasah

\begin{abstract}
Abstrak
Merespon tingginya angka kekerasan seksual terhadap anak-anak, Presiden Jokowi menetapkan Perpu Perlindungan Anak yang didalamnya mengatur hukuman kebiri kimia sebagai pidana tambahan bagi pelaku kekerasan seksual. Namun, selang beberapa tahun pasca ditetapkannya, kasus kekerasan seksual terhadap anak tetap tinggi, tapi faktanya tidak ada pelaku kekerasan seksual yang
\end{abstract}


dikebiri kimia. Sebab, kompetensi untuk melakukan kebiri kimia ada pada profesi dokter, namun Ikatan Dokter Indonesia (IDI) menolak menjadi eksekutor kebiri kimia, dengan alasan kemanusian dan menyalahi sumpah kedokteran. Atas dasar itu pula, kebiri kimia perlu ditelaah dalam perspektif Fiqh Siyasah. Penelitian ini merupakan penelitian sosiolegal, yang bertumpu pada data kualitatif, olehnya itu maka untuk mendeskripsikan hukuman kebiri kimia dalam perspektif Fiqh Siyasah, penulis menggunakan dua pendekatan, yaitu pendekatan perundangundangan dan pendekatan konseptual. Hasil penelitian menunjukkan bahwa, dinormakannya kebiri kimia sebagai salah satu jenis pidana tambahan bagi pelaku kekerasan seksual didasari atas pertimbangan bahwa (i) kekerasan seksual terhadap anak merupakan kejahatan yang sangat berbahaya karena tindak kejahatan ini tidak nampak kepermukaan, (ii) menimbulkan banyak korban yang disertai dengan trauma panjang, (iii) bahkan dapat mendorong korbannya untuk melakukan bunuh diri. (iv) Selain itu, pelakunya pun bukan hanya warga negara Indonesia, tetapi warga negara asing yang datang ke Indonesia berkedok wisatawan dan punya hasrat untuk mencari korban. Namun, terlepas dari pertimbangan tersebut, dalam perspektif fiqh siyasah, dengan berdasar pada kesepakatan para ulama penerapan kebiri kimia kepada pelaku kekerasan seksual adalah haram hukumnya. Tetapi bagi pelakunya dapat dijatuhi hukuman mati, jika perbuatannya dilakukan berulang kali.

\section{Kata Kunci : Kebiri Kimia; Kekerasan Seksual; Fiqh Siyasah}

\section{A. Latar Belakang Masalah}

Di dalam Islam, seorang kepala negara diberi otoritas yang begitu luas termasuk dalam menetapkan suatu aturan atau kebijakan. Namun demikian, pengambilan suatu keputusan oleh seorang kepala negara tidak boleh menyalahi aturan agama. Karena seperti yang dikatakan para pakar bahwa yang membuat undang-undang di dalam Islam adalah Allah SWT yang tertuang dalam al-Qur'an maupun hadis Nabi. ${ }^{1}$

Di sisi lain, aturan yang dikeluarkan oleh seorang kepala negara harus dipatuhi dan ditaati oleh rakyat selama aturan tersebut berdasar pada al-Qur'an dan hadis Nabi. Adanya ketaatan kepada seorang kepala negara sesungguhnya terimplementasi berdasarkan al-Qur'an dan hadis Nabi sendiri. Allah berfirman:

\footnotetext{
${ }^{1}$ Subhi Mahmasani,1980, Falsafatu Attasyri' fi al-Islam, Dar Ilmi Lilmalayin, Bairut, hal.255.
} 
"Hai orang-orang yang beriman, taatilah Allah dan taatilah Rasul (Nya), dan ulil amri di antara kamu. Kemudian jika kamu berlainan pendapat tentang sesuatu, maka kembalikanlah ia kepada Allah (Al Quran) dan Rasul (sunnahnya), jika kamu benar-benar beriman kepada Allah dan hari kemudian. Yang demikian itu lebih utama (bagimu) dan lebih baik akibatnya". (QS. Annisa: 59).

Begitupula dalam hadis Nabi terdapat penegasan tentang pentingnya taat kepada seorang pemimpin. Di antaranya hadis yang diriwayatkan oleh Abu Hurairah, Nabi bersabda:

"Barangsiapa yang mentaatiku maka sungguh ia taat kepada Allah, dan barangsiapa yang mendurhakaiku maka sungguh ia telah mendurhakai Allah. Dan barangsiapa yang mentaati raja maka ia mentaatiku; dan barangsiapa yang mendurhakai raja maka ia mendurhakaiku". ${ }^{2}$

Seorang kepala negara harus mampu menjaga dengan baik apa yang disebut al-masalih addaruriyyah atau addaruriyyat al-khamsah yakni: menjaga agama, menjaga jiwa, menjaga akal, menjaga keturunan, menjaga kehormatan, serta menjaga harta. Itulah sebabnya mengapa para pemimpin terdahulu sejak masa khulafaurrasyidin, telah melakukan ijtihad untuk mencari solusi hukum terkait dengan masalah yang dihadapi oleh mereka. Ijtihad seorang presiden dalam hal politik dan adiministrasi negara terkadang mengalami perubahan disebabkan karena berubahnya kondisi atau keadaan. Perubahan tersebut lumrah dijumpai dalam sejarah. Sebagai contoh, Umar bin Khattab dalam suatu masa tertentu pernah mengambil suatu kebijakan hukum tertentu lalu kemudian pada waktu yang lain mengambil suatu kebijakan hukum yang berbeda dengan yang pertama padahal kasusnya sama. Ketika Umar bin Khattab ditanya tentang perubahan yang dimaksud, beliau mengatakan: ini yang kami ketahui dan ini juga yang kami ketahui. Maksud dari pernyataan tersebut sesungguhnya adalah bahwa

\section{Jld.6.hal.4.}

${ }^{2}$ Hadis riwayat Baihaqi,1410 H, Syuabu al-Iman, Dar al-Kutub al-Ilmiyah, Beirut, 
beliau telah memutuskan perkara yang sama dengan hukum yang berbeda sesuai dengan ilmu dan ijtihadnya. Bahkan beliau seringkali tidak mengambil kebijakan hukum yang diputuskan oleh para pendahulunya disebabkan karena kondisi atau keadaan yang berubah dengan masa sebelumnya. ${ }^{3}$

Dalam konteks ini Ibnu Qayyim al-Jauziyah mengatakan: "Berubah dan berbedanya sebuah fatwa tergantung dengan berubahnya zaman, tempat, kondisi, niat dan manfaat". ${ }^{4}$ Namun berubahnya suatu hukum agama disebabkan karena adanya perubahan kondisi hanya terjadi pada masalah yang tidak berkaitan dengan akidah dan ibadah. Ibnu Qayyim al-Jauziyah kembali menegaskan: "Sesungguhnya hukum dan maslahat terbagi dua: pertama, ada bagian yang tidak berubah seperti hukum wajibnya sesuatu yang memang wajib, haramnya sesuatu yang memang haram, misalnya haramnya mencuri, haramnya berzina, haramnya membunuh, haramnya berlaku zalim, dan juga misalnya halalnya jual beli, halalnya sewa menyewa, dan halalnya menikah. Kedua, hal-hal yang berubah dengan berubahnya maslahat waktu dan tempat, dan kondisi seperti jumlah kadar ta'zir dan jenis-jenisnya". 5

Berdasar pada kaedah tersebut, dalam mengambil keputusan hukum harus mendalami sisi-sisi maslahat objek yang dituju, karena maslahat merupakan illat suatu hukum sekaligus menjadi dasarnya. Para ulama usul fiqh mengatakan: "Sesungguhnya suatu hukum agama yang terbangun atas adanya illat, ada tidaknya hukum tersebut tergantung pada illat-nya". ${ }^{6}$ Karena itu kepala negara harus lebih cermat melihat maslahat dan illat sesuatu dibalik adanya suatu perintah atau larangan agar tidak ceroboh dalam mengambil suatu kebijakan hukum, fatwa atau sesuatu yang bersifat putusan.

Dalam konteks ke Indonesiaan, sebagiamana telah diuraikan sebelumnya, maka Presiden Joko Widodo sebagai seorang kepala negara dan kepala pemerintahan juga harus mampu menjaga dengan baik apa yang disebut al-

\footnotetext{
${ }^{3}$ Yusuf Qardawi, Al-Siyasah al-Syar'iyyah, Maktabah Wahbah,Kairo, hal.127.

${ }^{4}$ Ibnu Qayyim al-Jauziyah, I'lam al-Muwaqqiin, Dar al-Hadis, Kairo, Jld.2.hal.1.

${ }^{5}$ Ibu Qayyim al-Jauziyah, Igatsah Allahfan, (t.t) Jld.1.hal.346.

${ }^{6}$ Subhi Mahmasani, Opcit, hal.222.
} 
masalih addaruriyyah atau addaruriyyat al-khamsah yakni: menjaga agama, menjaga jiwa, menjaga akal, menjaga keturunan, menjaga kehormatan, serta menjaga harta. Hal ini sejalan dengan apa yang telah diamanahkan oleh para pendiri bangsa, sebagaimana ditegaskan dalam alinea keempat pembukaan UUD $1945^{7}$ yang menyebutkan bahwa tujuan dibentuknya pemerintahan negara Indonesia adalah selain untuk melindungi segenap bangsa Indonesia dan seluruh tumpah darah Indonesia, juga bertujuan untuk memajukan kesejahteraan umum serta mencerdaskan kehidupan bangsa.

Namun, realitasnya terkhusus kepada anak sebagai generasi pelanjut estafet pembangunan bangsa yang memiliki peran strategis serta mempunyai ciri dan sifat khusus dalam menjamin keberlangsungan bangsa dan negara di masa yang akan datang, pada prinsipnya harus dijaga dan dilindungi oleh negara dari rusaknya jiwa, akal, agama, serta kehormatan, malah tidak mendapatkan perlindungan secara memadai. Ruang aman bagi anak-anak semakin sempit, anakanak Indonesia semakin rentang dengan berbagai bentuk ancaman dan kekerasan, terutama kekerasan seksual yang pelakunya tidak hanya berasal dari Indonesia tetapi adapula yang berasal dari negara lain. Padahal, hak konstitusional anak telah diatur secara tegas dalam UUD 1945, Pasal 28 B Ayat 2 yang menyebutkan bahwa "setiap anak berhak atas kelangsungan hidup, tumbuh, dan berkembang serta berhak atas perlindungan dari kekerasan dan diskriminasi”. Jaminan atas hak anak dikuatkan pula melalui ratifikasi konvensi internasional tentang hak anak melalui Keputusan Presiden No. 36 tahun 1990 tentang Convention On The Rights Of The Child. Selanjutnya, untuk lebih menguatkan eksistensi dalam menjamin dilaksanakannya hak ini dan sebagai wujud komitmen Indonesia dalam ratifikasi konvensi internasional tersebut, maka dibentuk pula Undang-Undang No. 23 Tahun 2002 Tentang Perlindungan Anak yang menegaskan negara dan pemerintah berkewajiban dan bertanggung jawab untuk menghormati dan menjamin hak asasi setiap anak tanpa diskriminasi serta berkewajiban dan

${ }^{7}$ Tujuan Nasional dalam UUD 1945, yaitu melindungi segenap bangsa Indonesia dan seluruh tumpah darah Indonesia dan untuk memajukan kesejahteraan umum, mencerdaskan kehidupan bangsa, dan ikut melaksanakan ketertiban dunia yang berdasarkan kemerdekaan, perdamaian abadi dan keadilan sosial. 
bertanggung jawab dalam memberikan dukungan dan prasarana dalam penyelenggaraan perlindungan anak ${ }^{8}$

Terbatasnya ruang aman bagi anak merupakan bentuk kelalaian atas kewajiban dan tanggung jawab negara dalam melindungi dan menghormati hak anak sehingga Indonesia menjadi negara dengan kasus kekerasan seksual (pedofilia) tertinggi di Asia sebagaimana informasi yang diperoleh Kepolisian RI dari intelegen Amierika (FBI) pada tahun 2014. Bahkan, pada seminar yang pernah diselenggarakan di Bangkok, Thailand dengan tajuk "Child Sex Tourism" Salah seorang petinggi kepolisian Australian Fedearal Police (AFP) memberikan pernyaataan bahwa pada tahun 2011, terdapat sedikitnya 1.194 pelaku kekerasan seksual yang sudah dipidana di Australia datang berkunjung ke Indonesia ${ }^{9}$ dan tentunya mereka sangat potensial untuk mengulangi kejahatan yang sama terhadap anak-anak di Indonesia dengan modus sebagai wisatawan.

Walaupun tidak ada data yang terungkap ke publik mengenai siapa saja warga negara asing (WNA) terpidana pelaku kekerasan seksual yang berkunjung ke Indonesia berkedok wisatawan, namun pada faktanya bahwa terdapat beberapa WNA yang telah divonis bersalah karena melakukan kekerasan seksual di Indonesia. Mereka diantaranya adalah; Robert Ellis (2006) wisatawan asal Australia, telah dijatuhi vonis 15 tahun penjara karena terbukti melakukan kekerasan seksual terhadap sebelas anak di Bali. ${ }^{10}$ Selain Robert Ellis, warga negara Asutralia yang telah dijatuhi hukuman karena melakukan kekerasan seksual terhadap anak adalah Tony William Stuart Borm (2004) yang mencabuli dua remaja berumur 14 tahun dan 16 tahun dan telah divonis 15 tahun penjara. Selain warga negara Australia, pelaku kekerasan seksual di Indonesia juga berasal dari negara lainnya, seperti Mario Manara (Italia) yang divonis 9 bulan penjara

\footnotetext{
${ }^{8}$ Liha Pasal 21 dan 22 UU No. 32 Tahun 2002 sebagaimana telah dirubah dengan UU No. 35 Tahun 2014 tentang Perlindungan Anak

9 Tempo.Co. Surga Pedofilia Bernama Nusantara, Sumber https://majalah.tem po.co/read/laporan-utama/ 145293/surga-pedofilia-bernama-nusantara?hidden= login, diakses Rabu, 25 Maret 2020

${ }^{10}$ Tribunnews.com, Robert Ellis Dihukum 15 Tahun Penjara di Bali, Sumber: https://www.tribunnews.com/australia-plus/2016/10/26/robert-ellis-dihukum-15-tahun-penjara-dibali. Diakses, Kamis, 26 Maret 2020
} 
karena mencabuli sembilan anak di Buleleng, Bali tahun 2001, Neil Bantleman (Kanada) yang melakukan pelecehan seksual pada anak TK Jakarta International School (JIS) tahun 2013-2014 dan telah divonis 11 tahun penjara ${ }^{11}$.

Selain WNA, pelaku kekerasan seksual juga merupakan warga negara Indonesia sendiri, diantaranya adalah Bekuni alias Babe (2010) yang divonis seumur hidup karena melakukan tindakan pencabulan (sodomi) terhadap anak jalanan serta membunuh 14 korbannya. Adapula Chandra Adi Gunawan (2014) divonis 4 tahun penjara karena menyebarkan video porno anak-anak di bawah umur di daerah Surabaya. Selain itu,ada pula Agung Dermawan dijatuhi hukuman mati karena melakukan pelecehan seksual dan pembunuhan terhadap seorang anak usia 9 tahun pada tahun $2015 .^{12}$

Sebagaimana telah diuraikan sebelumnya, bahwa negara sedari awal telah memberikan jaminan perlindungan anak melalui undang-undang Perlindungan Anak, namun pada realitasnya undang-undang Perlindungan Anak dianggap tidak efektif dalam mencegah terjadinya kekerasan seksul terhadap anak. Faktor yang ditengarai sebagai salah satu penyebabnya adalah tidak adanya efek jera yang ditimbulkan dari vonis yang dijatuhkan hakim, Vonis hakim yang dijatuhkan terhadap para pelaku kekerasan seksual tergolong ringan. Menyadari akan hal itu, pada tahun 2014, Undang-Undang No. 23 Tahun 2002 Tentang Perlindungan Anak kemudian diubah menjadi UU No. 35 Tahun 2014 dengan dasar bahwa pemberatan sanksi pidana dan denda bagi pelaku perlu ditingkatkan agar menimbulkan efek jera. ${ }^{13}$ Namun, kenyataannya pemberatan sanksi pidana tidak serta merta menurungkan tingkat kekerasan seksual terhadap anak, sehingga Pemerintah harus mengambil langkah pencegahan (preventif) dengan cara hukuman kebiri kimia dijadikan hukum positif di Indonesia.

11 Neil Bantlemen, kemudian dibebaskan karena mendapatkan grasi dari Presiden berdasarkan keputusan Presiden RI No 13/G Tahun 2019, Lihat https://megapolitan. kompas.com/read/2019/07/12/17541491/mantan-terpidana-kasus-pelecehan-seksual-jis-neil-bantle man-sudah-kembali, diakses 26 Maret 2020

12 Kumparan.com, 12 Kasus Pedofilia di Indonesia, sumber: https://kumparan.com /kumparannews/12-kasus-pedofilia-di-indonesia. Diakses Rabu, 25 Maret 2020

${ }^{13}$ Lihat Penjelasan UU No. 35 Tahun 2014 tentang Perubahan Atas UU No. 23 Tahun 2002 tentang Perlindungan Anak 
Argumentasi ini kemudian menjadi salah satu faktor pendorong Presiden Jokowi menerbitkan Peraturan Pemerintah Pengganti Undang-Undang No. 1 Tahun 2016 tentang Perlindungan Anak yang memberikan landasan hukum bagi penerapan kebiri kimia bagi pelaku kekerasan seksual. Ketentuan ini diatur dalam Pasal 81 Ayat 7, kebiri kimia dinormakan sebagai pidana tambahan bagi pelaku kekerasan seksual terhadap anak yang pelaksanaannya akan dikenakan kepada pelaku setelah terpidana menjalani hukuman pidana pokok paling lama dua tahun.

Pasca dinormakannya, kebiri kimia sebagai bagian dari hukum positif di Indonesia dalam penerapannya tidak serta merta dapat diterapkan bagi pelaku, bahkan organisasi profesi kedokteran, Ikatan Dokter Indonesia (IDI) yang sebenarnya memiliki kompetensi untuk menjadi tim eksekuor kebiri kimia terhadap pelaku, malah menolak tugas tersebut.

Ikatan Dokter Indonesia beralasan, kebiri kimia merupakan hukuman yang tidak manusiawi serta bertentangan dengan sumpah profesi kedokteran. Olehnya, maka penulis pula akan meninjau hukuman kebiri kimia dalam kacamata fiqh siyasah, apakah hukuman kebiri kimia, memang telah sesuai dengan ajaran agama Islam ataukah bertentangan dengan ajaran Islam. Untuk itu, dalam penulisan ini akan mengkaji dua hal, Perempuan dan Anak sebagai Obyek Kekerasan Seksual serta tinjauan kebiria kimia bagi pelaku kekerasan seksual berdasarkan perspektif fiqh siyasah.

\section{B. Metode Penelitian}

Penelitian ini merupakan penelitian deskriptif analisis dengan menggunakan tipe kajian sosiolegal. Pendekatan yang digunakan adalah pendekatan perundang-undangan dan pendekatan konseptual. Data yang digunakan adalah data kualitatif yang datanya diperoleh atau bersumber dari data skunder berupa bahan hukum primer Undang-Undang dasar 1945, UndangUndang serta Perppu Perlindungan Anak, UU Tindak Pidana Perdagangan Orang, Undang-Undang Hak Asasi Manusia, RUU Penghapusan Kekerasan Seksual maupun Al Quran dan Hadits. Serta bahan hukum sekunder, berupa karya ilmiah, 
buku-buku, laporan-laporan dan kitab-kitab serta karya ilmiah lainnya yang berkaitan dengan kebiri kimia dan kekerasan seksual terhadap perempuan dan anak. Berdasarkan jenis dan sumber data, maka teknik pengumpulan data yang digunakan adalah dengan cara studi dokumen berupa pengumpulan data melalui pengumpulan informasi kepustakaan atau bahan-bahan dokumen. Data yang diperoleh dalam penelitian selanjutnya dideskripsikan untuk mengkaji dan mendeskripsikan hukuman kebiri kimia bagi pelaku kekerasan seksual dalam perspektif Fiqh Siyasah.

\section{Pembahasan}

\section{Perempuan dan Anak Sebagai Obyek Kekerasan Seksual}

Dalam Kamus Besar Bahasa Indonesia, kekerasan diartikan sebagai suatu perbuatan baik yang dilakukan oleh seseorang maupun kelompok yang menimbulkan atau menyebabkan kerusakan fisik atau meninggalnya orang lain, dan atau menyebabkan kerusakan barang orang lain. Sedangkan seksual adalah berkenaan dengan perihal persetubuhan antara laki-laki dan perempuan. ${ }^{14}$ Didalam dunia hukum, defenisi atau kategori kekerasan, tidak hanya terkait dengan timbulnya kerusakan secara fisik, namun meliputi pula perbuatan yang dapat menimbulkan kesengsaraan atau penderitaan secara psikis serta seksual. Bahkan Undang-Undang Perlindungan Anak, mendefinisikan kekerasan sebagai perbuatan yang ditujukan terhadap anak yang menimbulkan kesengsaraan (penderitaan) baik yang berupa penderitaan fisik, psikis, seksual, dan atau penelantaran, serta termasuk pula tindakan melakukan ancaman untuk melakukan perbuatan, pemaksaan, atau perampasan kemerdekaan secara melawan hukum. ${ }^{15}$

Perluasan makna tentang kekerasan dalam dunia hukum tentu bukan tanpa alasan. Sebab seiring dengan kondisi sosial masyarakat yang terus berubah kearah modernitas, tentu pula akan mempengaruhi prilaku hukum seseorang dalam bermasyarakat. Setidaknya, akan menimbulkan dua prilaku hukum yaitu prilaku

\footnotetext{
${ }^{14}$ Kamus Besar Bahasa Indonesia, 2005, Balai Pustaka, Jakarta.

${ }^{15}$ Lihat Pasal 1 Ayat 15a UU No. 35 Tahun 2014 Tentang Perubahan Atas UU No. 23 Tahun 2002 Tentang Perlindungan Anak.
} 
taat hukum serta prilaku melawan hukum. Prilaku melawan hukum inilah yang kemudian akan mengganggu keseimbangan dalam masyarakat. Bahkan, tidak jarang terdapat individu atau kelompok dari masyarakat yang melakukan prilaku melawan hukum diluar nalar kemanusian yang korban kebanyakan berasal dari kaum perempuan dan anak-anak.

Sebagai contoh, pada tahun 2016 di daerah Bengkulu, kasus tragis menimpa gadis belia berusia 14 tahun bernama Yuyun. Ia meregang nyawa akibat menerima hantaman benda tumpul dibagian kepalanya. Selain mendapatkan kekerasan fisik, Yuyun juga mendapat kekerasan seksual berupa tindakan pemerkosaan yang dilakukan oleh 14 orang anak laki-laki yang usianya sebagian besar masih dibawah 20 tahun. ${ }^{16}$ Di daerah Tangerang, pada tahun 2016 nasib tragis juga menimpa perempuan bernama Eno Fariha (18 Tahun), ia tewas dibunuh ditangan tiga orang laki-laki yang salah satu pelakunya masih berusia 16 tahun. Tak jauh beda dengan perlakuan kekerasan yang dialami Yuyun, sebelum tewas, Eno Fariah juga mendapatkan tindak kekerasan seksual berupa pemerkosaan yang dilakukan oleh ketiga pelaku. ${ }^{17}$

Ibarat fenomena gunung es, nasib tragis yang menimpa Yuyun dan Eno Fariha hanyalah gambaran kecil dari kasus kekerasan seksual yang muncul kepermukaan. Sebab jika ditelaah lebih jauh, terdapat berbagai bentuk dan pola kekerasan seksual yang dapat menimpa perempuan baik terhadap perempuan dewasa maupun anak-anak. Dalam RUU Penghapusan Kekerasan Seksual seksual (RUU PKS) misalnya, kekerasan seksual didefinisikan sebagai setiap perbuatan yang merendahkan, menghina, menyerang, dan/atau perbuatan lainnya terhadap tubuh, hasrat seksual seseorang, dan atau fungsi reproduksi lainnya terhadap tubuh, hasrat secara paksa, bertentangan dengan kehendak seseorang, yang

\footnotetext{
${ }^{16}$ Liputan6.com, Kronologi Kasus Kematian Yuyun di Tangan 14 ABG Bengkul. Sumber: https://www.liputan6.com/regional/read/2499720/kronologi-kasus-kematian-yuyun-di-tangan-14abg-bengkulu. Diakses Rabu, 11 Maret 2020.

${ }^{17}$ DetikNews.com, Jalan Panjang Pembunuhan Sadis Eno yang Berujung Hukuman Mati, Sumber : https://news.detik.com/berita/d-3417513/jalan-panjang-pembunuhan-sadis-enoyang-berujung-vonis-mati?_ga=2 .201689233.1240205547.1583897755-888393700.1572396624. Diakses 11 Maret 2020, pukul 11.30 Wita. Lihat pula https://www.merdeka.com/peristiwa/inikronologi-lengkap-pembunuhan-sadis-enno-farihah-pakai-cangkul. html. Diakse Rabu, 11 Maret 2020
} 
menyebabkan seseorang itu tidak mampu memberikan persetujuan dalam keadaan bebas, karena ketimpangan relasi kuasa dan atau relasi gender, yang berakibat atau dapat berakibat penderitaan atau kesengsaraan secara fisik, psikis, seksual, kerugian secara ekonomi, sosial, budaya, dan atau politik. Adapun bentuk-bentuk kekerasan seksual sebagaimana dirumuskan dalam RUU PKS tersebut adalah dapat berupa (i) pelecehan seksual (ii) eksploitasi seksual (iii) pemaksaan kontrasepsi (iv) pemaksaan aborsi (v) perkosaan (vi) pemaksaan perkawinan (vii) pemaksaan pelacuran (viii) perbudakan seksual, dan atau (ix) penyiksaan seksual. $^{18}$

Dicetuskannya RUU PKS sebagai bagian dari politik hukum pemerintah dalam melindungi perempuan dari kekerasan seksual, tak lain dilatari oleh terjadinya peningkatan angka kekerasan seksual terhadap perempuan dan anak. Argumentasi ini berdasarkan pada Catatan Tahunan (CATAHU) Komisi Nasional Perempuan tahun 2018 yang berisi tentang besaran dan gambaran umum bentuk kekerasan yang menimpa perempuan Indonesia serta data dari Komisi Nasional Perlindungan Anak (KPAI) terkait kekerasan seksual terhadap anak tahun 20112016.

Demi memudahkan memahami bentuk kekerasan terhadap perempuan, Catahu 2018 Komnas perempuan, membagi tiga wilayah yang menjadi ruang lingkup terjadinya kekerasan terhadap perempuan. Ketiga ruang lingkup yang dimaksud yaitu meliputi lingkup personal (privat), komunitas (publik) serta ruang lingkup negara ${ }^{19}$. Namun khusus untuk kekerasan seksual yang menimpa perempuan, berdasarkan CATAHU 2018 tersebut, kekerasan seksual terhadap perempuan hanya terjadi pada ruang lingkup personal/privat dan komunitas (publik), tidak ada data yang menyebutkan terjadinya kekerasan seksual terhadap perempuan berdasarkan ruang lingkup negara.

\footnotetext{
${ }^{18}$ Lihat RUU Penghapusan Kekerasan Seksual, versi DPR RI, Sumber: https://www.dpr.go.id /doksileg/proses2/RJ2-20170201-043128-3029.pdf. Diakses Kamis, 26 Maret 2020

${ }^{19}$ Pada ruang lingkup negara, pelaku kekerasan terhadap perempuan merupakan aparatur sipil negara yang melaksanakan tugas. Termasuk dalam ranah negara, yaitu ketika terjadi pristiwa kekerasan, aparatur negara yang berada pada lokasi kejadian, tidak berupaya untuk menghentikan atau malah justru membiarkan tindak kekerasan berlanjut.
} 
Petama, pada ruang lingkup privat/personal korban, pelaku merupakan orang yang memiliki hubungan darah (seperti ayah, kakak, adik, paman dan kakek), hubungan kekerabatan, hubungan perkawinan (suami), serta hubungan relasi intim atau pacaran dengan korban. Kedua, lingkup komunitas (publik). Pada ranah ini pelaku dan korban tidak memiliki hubungan darah, kekerabatan, atau perkawinan, sehingga pelaku kekerasan seksual dapat berasal dari rekan kerja, guru, majikan, tetangga, tokoh masyarakat ataupun orang yang tidak dikenali oleh korban. $^{20}$

Atas dasar klasifikasi tersebut, Komnas Perempuan melaporkan bahwa pada ranah privat/personal. Kasus kekerasan seksual yang pelakunya berasal dari orang terdekat korban (incest), merupakan kasus terbanyak yang dilaporkan, yaitu 1,210 kasus. Kemudian, terbanyak laporan kedua, yaitu kasus pemerkosaan sebanyak 619 kasus, dan ketiga kasus eksploitasi seksual/persetubuhan sebanyak 555 kasus. Untuk kasus incest (pelaku memiliki hubungan darah dengan korban) misalnya, terdapat 425 kasus yang pelakunya merupakan ayah kandung korban dan 425 kasus yang pelakunya merupakan paman korban. Sedangkan, kasus yang beradasarkan hubungan relasi intim (pacaran dengan korban), terdapat 1.528 kasus yang dilaporkan.

Pada ruang lingkup publik/komunitas, jumlah kekerasan seksual terhadap perempuan mencapai angka 911 kasus untuk kasus pencabulan, pelecehan seksual 708 kasus, serta terdapat 699 kasus pemerkosaaan yang dilaporkan. ${ }^{21}$ Memang harus diakui bahwa kaum perempuan dan anak sering mengalami kekerasan dalam kehidupan masyarakat, baik kekerasan itu dalam bentuk fisik maupun mental karena dipengaruhi oleh ketimpangan relasi kuasa yang menempatkan posisi laki-laki lebih superior dari pada perempuan yang inferior.

Disamping itu, ada pihak-pihak tertentu yang memandang perempuan dan anak sebagai obyek komoditi yang dapat dikomersilkan dan dieksploitasi, baik

\footnotetext{
${ }^{20}$ Lihat lembar fakta dan poin kunci Catatan Tahunan Komnas Perempuan Tahun 2018 “ Tergerusnya Ruang Aman Perempuan Dalam Pusaran Politik Populisme, yang dilansir pada 7 Maret 2018. Sumber: https://www.komnasperempuan.go.id/file/pdf_file/2018/SIARAN\% 20PERS\%202018/Lembar\%20Fakta\%20Catahu\%207\%20Maret\%202018.pdf. Diakses, Ahad 22 Maret 2020.

${ }^{21}$ Ibid, hal 3.
} 
eksploitasi secara seksual maupun eksploitasi dalam bentuk lainnya. Cara pandang inilah yang kemudian membentuk relasi simbiosis mutualisme pada kasus tindak pidana perdagangan orang (trafficking). Dalam rentang waktu 20112013 data pihak Kepolisian Negara Republik Indonesia, menyebutkan bahwa terdapat 509 (lima ratus Sembilan) kasus tindak pidana perdagangan orang (TPPO). Diantara 509 kasus TPPO tersebut, terdapat 205 (dua ratus lima) kasus terkait eksploitasi seksual. Sedangkan jika dilihat dari korbannya, data menunjukkan bahwa mayoritas korban TPPO adalah perempuan dewasa dan anak perempuan, dengan rincian korban perempuan dewasa mencapai 418 orang serta 218 orang anak perempuan. ${ }^{22}$

Sedangkan untuk melihat dan memahami angka kasus kekerasan seksual khusus terhadap anak, lebih rinci dapat dilihat dari data publikasi Komisi Nas Perlindungan Anak Indonesia (KPAI) sebagaimana table dibawah ini.

\section{Tabel 1}

Jumlah Anak Sebagai Korban Maupun Pelaku Kekerasan Seksual (baik dalam kasus pemerkosaan, pelecehan, pencabulan/sodomi dll)

Tahun 2011-2016

\begin{tabular}{ccc}
\hline Tahun & $\begin{array}{c}\text { Jumlah Anak Sebagai Korban } \\
\text { Kekerasan Seksual }\end{array}$ & $\begin{array}{c}\text { Jumlah Anak Sebagai Pelaku } \\
\text { Kekerasan Seksual }\end{array}$ \\
\hline 2011 & 216 & 123 \\
2012 & 412 & 324 \\
2013 & 343 & 247 \\
2014 & 656 & 561 \\
2015 & 218 & 157 \\
2016 & 120 & 86 \\
\hline
\end{tabular}

Sumber : Bank Data KPAI ${ }^{23}$

${ }^{22}$ Sedangkan korban berjenis kelamin laki-laki berjumlah 115 orang laki-laki dewasa dan tiga orang anak laki-laki

${ }^{23}$ Kpai.go.id, Rincian Data Kasus Berdasarkan Klaster Perlindungan Anak, Sumber : https://bankdata.kpai.go.id/tabulasi-data/data-kasus-per-tahun/rincian-data-kasus-berdasarkanklaster-perlindungan-anak-2011-2016. Dakses Rabu, 1 April 2020 
Berdasarkan pada Tabel 1 diatas, dapat dijelaskan bahwa dalam rentang waktu 2011 sampai dengan 2016 menunjukkan bahwa anak sebagai generasi pelanjut bangsa tidak hanya menjadi korban dari kekerasan seksual, namun adapula yang bertindak sebagai pelaku. Adapun jumlah anak yang menjadi korban kekerasan seksual, baik sebagai korban pemerkosaan, pencabulan, sodomi/pedofilia, dan sebagainya, menunjukkan bahwa pada tahun 2011 terdapat 216 anak menjadi korban kekerasan seksual, mengalami peningkatan pada tahun 2012 sebanyak 412 anak, dan meningkat lagi ditahun 2013 sebanyak 343 anak. Anak sebagai korban kekerasan seksual, kemudian mengalami peningkatan yang cukup signifikan ditahun 2014 sebanyak 656 anak. Lalu pada tahun 2015 dan 2016 terjadi tren penurunan jumlah anak yang menjadi korban kekerasan seksual, yaitu tahun 2015 terdapat 218 korban dan tahun 2016 terdapat 120 korban. Walaupun pada tahun 2015 dan 2016 terjadi tren penurunan jumlah korban namun data ini menjadi peringatan bagi pemerintah dan masyarakat bahwa dalam setahun setidaknya terdapat lebih dari seratusan anak-anak Indonesia yang menjadi korban kekerasan seksual.

Berdasarkan klaster sebagai pelaku, anak sebagai generasi bangsa juga tidak luput dari aksi tidak terpuji ini (baik sebagai pelaku pada kasus pemerkosaan, pencabulan, pedofilia/sodomi, dan sebagainya). Berdasarkan Tabel 1 kolom 3, dapat dijelaskan bahwa pada tahun 2011 setidaknya terdapat 123 anak menjadi pelaku kekerasan seksual. Ditahun 2012 terjadi peningkatan hampir tiga kali lipatnya yaitu sebanyak 324 anak. Pada tahun 2013 kembali turun menjadi 247 anak. Namun pada tahun 2014, terjadi peningkatan hingga mencapai angka 561 anak sebagai pelaku. Sedangkan ditahun 2015 dan 2016, mulai mengalami penurunan, yaitu 157 anak menjadi pelaku pada tahun 2015 dan di 2016 pelakunya hanya berjumlah 86 anak. Masih berdasarkan data dari KPAI, bahwa selain anak-anak menjadi korban dan pelaku kekerasan seksual berupa pemerkosaan, pencabulan maupun sodomi/pedofilia, ditemukan pula berbagai kasus yang menjerumuskan anak menjadi korban eksploitasi seks anak (ESKA) dan prostitusi online. 
Tabel 2

Data Jumlah Anak Sebagai Korban Eksploitasi Seks Anak (ESKA) dan Anak Sebagai Korban Prostitusi Online

Tahun 2011-2016

\begin{tabular}{lcc}
\hline Tahun & $\begin{array}{c}\text { Jumlah Anak Sebagai Korban } \\
\text { Eksploitasi Seks Anak (ESKA) }\end{array}$ & $\begin{array}{c}\text { Jumlah Anak Sebagai Korban } \\
\text { Prostitusi Online }\end{array}$ \\
\hline 2011 & 59 & 16 \\
2012 & 32 & 27 \\
2013 & 51 & 60 \\
2014 & 46 & 83 \\
2015 & 72 & 117 \\
2016 & 41 & 61 \\
\hline
\end{tabular}

Sumber : Bank Data $\mathrm{KPAI}^{24}$

Sedangkan berdasarkan klaster anak sebagai korban eksploitasi seks anak (ESKA), data menunjukkan bahwa pada tahun 2011, terdapat 59 anak yang menjadi korban, ditahun 2012 terdapat 32 anak. Pada tahun 2013, sebanyak 51 anak menjadi korban dan tahun 2014 terdapat 46 anak. Sedangkan pada tahun 2015, jumlah anak yang menjadi korban ESKA mencapai 72 anak, dan mengalami penurunan ditahun 2016, yaitu 41 anak. Untuk jumlah anak sebagai korban prostitusi online, berdasarkan klaster anak sebagai korban prostitusi online, dari tahun 2011-2016 menunjjukkan bahwa pada tahun 2011-2015 terjadi tren peningkatan jumlah korban yaitu 16 anak yang menjadi korban prostitusi online pada tahun 2011, naik menjadi 27 anak di tahun 2012, kemudian naik lagi sebanyak 60 anak di tahun 2013. Di 2014, naik lagi menjadi 83 anak menjadi korban, dan korban terbanyak di tahun 2015 sebanyak 117 anak dan pada tahun 2016 mulai turun menjadi 62 anak korban prostitusi online.

Jika ditinjau dalam sejarah peradaban umat manusia, maka sejarah tidak menafikan bahwa perlakuan terhadap kaum wanita terkadang tidak manusiawi, sebut saja misalnya ketika seorang budak bernama Mu'adzah yang dijual oleh

\footnotetext{
${ }^{24}$ Ibid, Bank Data KPAI. Diakses, Kamis, 26 Maret 2020
} 
majikannya bernama Abdullah bin Ubai bin Salul seorang munafik kepada seorang lelaki quraisy yang menjadi tawanan Ubai. Tujuan Ubay hanya satu yaitu jika Mu'adzah hamil dan melahirkan anak, lelaki quraisy itu akan menebusnya. Menyikapi hal tersebut, Mu'adzah yang mukminah itu menolak perlakuan itu dan membawa persoalannya kepada Nabi. Tidak lama kemudian, pengaduan perempuan itu serta merta mendapat jawaban dari Allah SWT sekaligus menjadi sebab turunnya ayat 33 surah an-Nur. Allah berfirman:

"Dan orang-orang yang tidak mampu kawin hendaklah menjaga kesucian (diri)nya, sehingga Allah memampukan mereka dengan karunia-Nya, dan budak-budak yang kamu miliki yang menginginkan perjanjian, hendaklah kamu buat perjanjian dengan mereka, jika kamu mengetahui ada kebaikan pada mereka, dan berikanlah kepada mereka sebahagian dari harta Allah yang dikaruniakan-Nya kepadamu. Dan janganlah kamu paksa budakbudak wanitamu untuk melakukan pelacuran, sedang mereka sendiri mengingini kesucian, karena kamu hendak mencari keuntungan duniawi. Dan barangsiapa yang memaksa mereka, maka sesungguhnya Allah adalah Maha Pengampun lagi Maha Penyayang (kepada mereka) sesudah mereka dipaksa itu”. (QS.Annur: 33).

Ayat al-Qur'an di atas dengan jelas memberikan penegasan tentang adanya penolakan terhadap kekerasan seksual dalam bentuk apapun termasuk eksploitasi seksual yang dilakukan oleh seorang majikan terhadap budak perempuannya untuk kepentingan komersial. Dari beberapa kasus dan pernyataan yang telah disinggung, bahwa dari segi perlindungan terhadap perempuan dan anak, maka negara sebenarnya dapat dikategorikan berada dalam kondisi kegentingan negara. Sebab disatu sisi, perempuan dipandang sebagai tiang negara yang setiap saat dapat terancam oleh predator seksual serta anak-anak sebagai generasi pelanjut estapet bangsa berada dalam bayang-bayang kekerasan seksual yang mampu merusak jiwa, akal serta kehormatan anak. 


\section{Kebiri Kimia, Respon Negara Atas Tingginya Angka Kekerasan Seksual Terhadap Anak}

Tingginya angka kekerasan seksual terhadap anak Indonesia tidak boleh dipandang sebelah mata dan dianggap sebagai kasus asusila semata. Sebab tidak satupun negara yang memungkiri bahwa asset terbesar yang dimiliki suatu bangsa adalah kelompok usia remaja dan anak-anak yang dimasa akan datang berperan dalam mengambil alih komando kepemimpinan suatu bangsa. Olehnya itu, dalam memahami tingginya angka kekerasan seksual terhadap anak, pemerintah maupun masyarakat harus memiliki persepsi yang sama dalam menanggulangi kejahatan seksual ini. Hal tersebut penting dan harus menjadi perhatian serius pemerintah, sebab kejahatan seksual yang menyasar anak-anak sebagai korban, dapat menimbulkan "efek domino" dikemudian hari, dimana berdasarkan pengalaman yang dialami korban kekerasan seksual, suatu waktu dikemudian hari berpotensi menjadi pelaku kekerasan seksual dengan menyasar anak-anak dilingkungan sekitarnya sebagai korban.

Asumsi ini tentu bukan isapan jempol belaka, karena berdasarkan penelusuran penulis, setidaknya terdapat tiga pelaku kekerasan seksual terhadap anak yang pernah menjadi korban kekerasan seksual. Ketiga pelaku tersebut, yaitu Baekuni, Zainal, dan Andri Sobari. Baekuni alias Babe (49 tahun) merupakan pelaku kekerasan seksual terhadap belasan anak jalanan di Jakarta, dalam perjalanan hidupnya ia pernah menjadi korban kekerasan seksual (sodomi) saat masih berusia 12 tahun. Sedangkan Zainal (28 tahun) pelaku kekerasan seksual di TK Jakarta International School (JIS) juga pernah menjadi korban kekerasan seksual sebanyak dua kali, yaitu saat ia berumur 5 tahun dan 14 tahun. Selain diwilayah Jakarta, di daerah Sukabumi, Jawa Timur, puluhan anak juga menjadi korban kekerasan seksual yang palakunya dilakukan oleh Andri Sobari alias Emon (24 tahun), sebelum menjadi pelaku kekerasan seksual, Andri juga pernah menjadi korban kekerasan seksual (sodomi) semasa SMP. ${ }^{25}$

${ }^{25}$ Detik.com, Korban Kekerasan Seksual yang Menjadi Pelaku Kala Dewasa, Sumber : https://news.detik.com/berita/d-2572489/korban-kekerasan-seksual-yang-menjadi-pelaku-kaladewasa/8. Diakses, Kamis, 2 April 2020 
Berdasarkan beberapa kasus yang telah diuraikan sebelumnya, maka kejahatan seksual terhadap anak dapat kita klasifikasikan sebagai extra ordinary crime (kejahatan luar biasa) dengan alasan: pertama dari segi pelaku. Pelaku kekerasan seksual terhadap anak tidak hanya berasal dari Indonesia, tetapi pelakunya sebahagian berasal dari luar negeri yang datang ke Indonesia sebagai wisatawan dan mencari korban. Kedua, kekerasan seksual terhadap anak merupakan kejahatan kemanusian yang sifatnya tidak nampak kepermukaan yang menimbulkan banyak korban. Karena sifatnya yang tidak tampak, maka kekerasan seksual terhadap anak, baru muncul kepermukaan jika korban atau salah satu dari korbannya melapor. Dan biasanya jika salah satu korban melapor, maka akan muncul korban-korban lainnya. Namun, jika tidak ada pengakuan dan laporan dari korban, maka kejahatan kekerasan seksual terhadap anak akan sulit terdeteksi dan menyebabkan pelaku kekerasan seksual berada pada zona aman untuk tetap berbaur ditengah masyarakat.

Dalam situasi ini, pelakunya lebih leluasa mencari korban. Konsekuensinya adalah semakin lambat kejatahatan seksual ini diketahui oleh publik, maka korban yang ditimbulkan akan semakin banyak, dan begitupula sebaliknya. Ketiga, Kejiwaan korban. Anak-anak yang menjadi korban kejahatan seksual tentu akan mengalami trauma panjang ${ }^{26}$ bahkan dapat berujung ke aksi bunuh diri. Trauma panjang yang dialami korban dapat berupa hilangnya kepercayaan anak terhadap orang dewasa (betrayal), merasa tidak berdaya (powerlessness), stigma (stigmatization), dan atau trauma secara seksual. Disamping itu, anak sebagai korban secara psikis dapat menimbulkan ketagihan, trauma, bahkan pelampiasan dendam ${ }^{27}$. Sehingga anak yang sebelumnya menjadi korban, dapat pula menjadi pelaku dikemudian hari sebagaimana pengalaman yang dilalui oleh Baekuni, Zainal, dan Andri Sobari.

\footnotetext{
${ }^{26}$ Hukumonline, Menkumham Kaji Wacana Hukuman Kebiri Pelaku Pedofi, Sumber : https://www.hukumonline.com/berita/baca/lt5628ee32df202/menkumham-kaji-wacana-hukumankebiri-pelaku-pedofil, diakses Ahad, tanggal 22 Maret 2020

27 Ivo, Noviana, "Kekerasan Seksual Terhadap Anak: Dampak dan Penanganannya." Sosio Informa Vol. 1, No. 1 (2015). Hal 1
} 
Dengan memahami sifat dan dampak yang ditimbulkan oleh prilaku kekerasan seksual terhadap anak, maka syogyanyalah, Presiden Joko Widodo mengambil kebijakan dalam menanggulangi kejahatan seksual. Dalam teori hukum, usaha negara atau masyarakat dalam menanggulangi kejahatan dikenal dengan teori kebijakan kriminal. Marc Ancel, menyebut bahwa kebijakan kriminal adalah "the rational organization of the control of crime by society ${ }^{28}$, atau munurut Sudarto, kebijakan kriminal merupakan suatu usaha yang rasional dari masyarakat dalam menanggulangi kejahatan. ${ }^{29}$ Lebih lanjut menurut Sudarto, kebijakan kriminal dapat dilakukan dengan dua sarana, yaitu sarana penal (pidana) atau sarana non penal. ${ }^{30}$

Berdasarkan teori kebijakan kriminal, Presiden Joko Widodo mengambil sikap dan turun tangan langsung dalam menaggulangi kejahatan kekerasan seksual melalui sarana penal (pidana). Langkah yang diambil adalah dengan jalan pintas, yaitu menerbitkan Peraturan Pemerintah Pengganti Undang-Undang (Perpu) Nomor 1 Tahun 2016 tentang Perlindungan Anak.

Didalam Perpu No. 1 Tahun 2016, maka pidana yang dapat dijatuhkan bagi pelaku kekerasan seksual dapat berupa pidana mati, pidana seumur hidup atau pidana paling singkat 10 tahun penjara dan maksimal 20 tahun penjara. Ketentuan ini diatur dalam Pasal 81 Ayat 5 Perpu No. 1 Tahun 2016 yang mengatur bahwa setiap orang yang melakukan kekerasan seksual atau ancaman kekerasan memaksa anak melakukan persetubuhan dengannya atau orang lain, ${ }^{31}$ dan menimbulkan korban lebih dari 1 (satu) orang, mengakibatkan luka berat, gangguan jiwa, penyakit menular, terganggu atau hilangnya fungsi reproduksi, dan atau korban meninggal dunia, pelakunya dipidana mati, seumur hidup, pidana penjara minimal 10 tahun dan maksimal 20 tahun.

\footnotetext{
${ }^{28}$ Barda Nawawi Arief (a),1996, Bunga Rampai Kebijakan Hukum Pidana, PT Citra Adutya Bakti, Bandung, hal.2

${ }^{29}$ Sudarto, 1986, Hukum dan Hukum Pidana, Alumni, Bandung, hal. 42.

${ }^{30}$ Barda Nawawi Arif, opcit, hal. 3

${ }^{31}$ Pasal 76D UU No. 35 Tahun 2004 tentang Perubahan Atas UU No. 23 Tahun 2002 tentang Perlindungan Anak.
} 
Sanksi pidana ini lebih berat dari ketentuan sebelumnya, yakni hanya mengatur sanksi pidana minimal 3 tahun penjara dan maksimal 15 tahun penjara yang dapat dijatuhkan bagi pelaku kekerasan seksual. Selain itu, untuk menimbulkan efek jera pelaku kekerasan seksual terhadap anak, maka pelaku dapat pula dijatuhi pidana tambahan berupa kebiri kimia ${ }^{32}$. Kebiri kimia ${ }^{33}$ sebagai salah satu pidana tambahan bagi pelaku kekerasan seksual anak dapat dijatuhkan apabila melakukan perbuatan yang melanggar Pasal 76D UU No. 35 Tahun 2014 yaitu "Setiap Orang dilarang melakukan Kekerasan atau ancaman Kekerasan memaksa anak melakukan persetubuhan dengannya atau dengan orang lain.” disamping itu, perbuatan pelaku menimbulkan korban lebih dari 1 (satu) orang, mengakibatkan luka berat, gangguan jiwa, penyakit menular, terganggu atau hilangnya fungsi reproduksi, dan atau korban meninggal dunia. Kebiri kimia dapat pula dijatuhkan kepada pelaku yang pernah dijatuhi pidana karena melakukan kekerasan seksual terhadap anak dan mengulangi perbuatannya kembali ${ }^{34}$. Namun, yang perlu dipahami pula bahwa hukuman kebiri kimia dikecualikan bagi pelaku anak.

\section{Hukuman Kebiri Dalam Islam}

Melihat maraknya kejahatan yang terjadi di tengah masyarakat Indonesia termasuk kejahatan seksual tentu semuanya setuju bahwa kejahatan sampai kapan pun tidak akan pernah mendapat ruang dan tempat di tengah masyarakat yang menjunjung tinggi nilai-nilai agama. Karena itu, Islam di sisi lain telah

${ }^{32}$ Kebiri kimia adalah suatu jenis hukuman yang dijatuhkan bagi pelaku pemerkosaan/ kekerasan seksual agar hasrat seksualnya mengalami penurunan, hukuman ini dilakukan dengan cara menyuntikkan zat anti-testosteran ketubuh pelaku.

${ }^{33}$ saat ini ada, terdapat 20 negara yang memberlakukan hukuman kebiri yakni 9 negaranegara Eropa dan 9 negara-negara bagian Amerika, satu negara Amerika Latin dan satu negara di Asia Tenggara. Kesembilan Negara Eropa tersebut adalah Inggris, Polandia, Rusia, Jerman, Republik Ceko, Denmark, Swedia dan Spanyol. Sedangkan Sembilan Negara bagian Amerika adalah California, Florida, Georgia, Iowa, Lousiana, Montana, Oregon, Texas dan Wisconsin. Satu Negara Amerika Latin yang memberlakukan hukuman kebiri adalah Agentina dan satu Negara di Asia Tenggara adalah Korea Selatan. Sumber: http://mappifhui.org/wpcontent/uploads/2016/03/Menguji-Eforia-Kebiri.pdf, diakses Kamis, 2 April 2020.

34 Pasal 81 Ayat 4 Perpu No. 1 Tahun 2016 berbunyi : Selain terhadap pelaku sebagaimana dimaksud pada ayat (3), penambahan 1/3 (sepertiga) dari ancaman pidana juga dikenakan kepada pelaku yang pernah dipidana karena melakukan tindak pidana sebagaimana dimaksud dalam Pasal 76D. 
mengakomodir adanya hukuman bagi para pelaku kejahatan yang disebut dengan ukubah. Tentu saja hukuman di dalam Islam yang dijatuhkan atas pelaku kejahatan sebagai penghinaan baginya; dan salah satu tujuannya adalah mencegah terjadinya kejahatan. ${ }^{35}$ Ukubah seperti yang dijelaskan dalam mazhab Hanbali adalah termasuk hudud dan qisas. ${ }^{36}$ Sedangkan hudud oleh Abul Hasan alMawardi dibagi ke dalam dua bagian. Pertama adalah hudud yang berkaitan dengan hak-hak Allah. Kedua adalah hudud yang berkaitan dengan hak-hak manusia. Hudud yang berkaitan dengan hak-hak Allah juga dibagi ke dalam dua bagian. Pertama: hudud yang diwajibkan karena meninggalkan hal-hal yang bersifat wajib. Kedua: hudud yang diwajibkan karena melakukan hal-hal yang dilarang oleh agama. ${ }^{37}$ Lalu kemudian, al-Mawardi menjelaskan bahwa hudud yang berkaitan dengan hak Allah seperti meninggalkan shalat wajib. Sedangkan hudud yang diwajibkan karena melakukan hal-hal yang dilarang oleh agama, alMawardi juga membagi ke dalam dua bagian. Pertama: yang berkaitan dengan hak-hak Allah seperti had zina, had minuman keras, had pencurian, had hirabah, dan had riddah. Sedangkan yang kedua adalah yang berkaitan dengan hak-hak manusia seperti had kazf azzina/menuduh orang lain melakukan zina, dan qawad/qisas dalam tindak kriminal seperti pembunuhan. ${ }^{38}$

Secara spesifik, semua bentuk pelanggaran yang dilakukan manusia telah tertera hukumnya di dalam Islam, baik dalam Al-Qur'an maupun dalam hadis nabi. Terkait boleh tidaknya hukuman kebiri pada manusia, para ulama telah sepakat bahwa hukumnya haram. ${ }^{39}$ Pengharaman tersebut berdasar pada beberapa hadis Nabi di antaranya hadis riwayat Abdullah. Beliau mengatakan: "Dahulu kami pernah berperang bersama Nabi SAW sedang kami tidak bersama isteriisteri. Lalu kami berkata kepada Nabi SAW, bolehkah kami melakukan kebiri?'

35 Kamal Ibnu al-Humam, al-Hidayah Ma'ah Fathil al-Qadir, Matba'ah Mustafa Muhammad, Kairo, Jld.4.hal.112. Lihat juga Al-Buhutiy, Kassyaf al-Qina, Matba'ah alSyarafiyah, Kairo, Jld.4.hal.47.

${ }^{36}$ Sa'diy Abu Jieb, al-Qamus al-Fikhiy, Dar al-fikri, Dimask, hal.255.

${ }^{37}$ Abu al-Hasan al-Mawardi, al-Ahkam al-Sulthaniyah, Dar al-Fikr, Bairut, hal.221.

${ }^{38}$ Ibid

${ }^{39}$ Mahmud bin Ahmad bin Assadr, al-Muhit al-Burhaniy, Dar Ihya Atturats al-Arabiy, Kairo, Jld.5.hal.244. Lihat juga Fiqh Annawazil, (Maktabah Syamilah), Jld.1.hal.163. 
Nabi SAW melarang kami". ${ }^{40}$ Dalam hadis yang lain yang diriwayatkan oleh Ibnu Abbas, Nabi mengatakan: "Dari Ibnu Abbas, Nabi bersabda: "Tidak ada pengebirian di dalam Islam". 41

Berdasar pada hadis yang disebutkan para ulama menyatakan bahwa haram hukumnya menerapkan hukuman kebiri untuk pelaku pedofilia, karena syariat Islam sudah menetapkan rincian hukuman tertentu bagi pelaku pedofilia. Adapun rincian hukuman untuk pelaku pedofilia sebagai berikut; (1) jika yang dilakukan pelaku pedofilia adalah perbuatan zina, maka hukumannya adalah hukuman untuk pezina (had az-zina) yaitu dirajam jika sudah muhsan (menikah) atau dicambuk seratus kali jika bukan muhsan; (2) jika yang dilakukan pelaku pedofilia adalah liwath (homoseksual), maka hukumannya adalah hukuman mati; (3) jika yang dilakukan adalah pelecehan seksual (attaharusy al-jinsi) yang tidak sampai pada perbuatan zina atau homoseksual, maka hukumannya adalah ta'zir.

Kendati demikian, di Indonesia ada sebagian kalangan yang setuju dengan hukuman kebiri tersebut dengan alasan mengedepankan aspek maslahat ketika hukum kebiri diterapkan. Di antara yang setuju adalah Ketua Komisi Dakwah dan Pengembangan Masyarakat Majelis Ulama Indonesia (MUI) Cholil Nafis. Ia menganggap bahwa pemberian hukuman kebiri pada terpidana pedofilia bisa memberikan efek jera (zawajir). Bahkan lebih jauh lagi ia mengatakan bahwa seorang hakim bisa saja berijtihad dalam memberikan hukuman dalam kasus ini dengan pertimbangan zawajir tadi. ${ }^{42}$

Hal yang sama juga dikatakan oleh Ovied R. Wakil Ketua Dewan Fatwa Pengurus Besar Al-Jam iyatul Washliyah (PB Al-Washliyah) bahwa pelaksanaan Peraturan Pemerintah Pengganti Undang-Undang (Perpu) Kebiri terhadap pelaku pemerkosaan, menurut hukum Islam dibolehkan dan halal. Menurutnya Perppu kebiri terhadap pelaku pemerkosaan disertai pembunuhan telah sejalan dengan

\footnotetext{
${ }^{40}$ Hadis riwayat Bukhari, 1987, Sahih Bukhari, Dar Ibni Katsir, Bairut, Jld.4.hal.1687.

${ }^{41}$ Hadis riwayat Jamaluddin Azzaila'iy, Nasbu Arrayah, Muassasah Arrayyan, Beirut, Jld.3.hal.353.

${ }^{42}$ Republika.co.id, Hukuman Kebiri dalam Tinjauan Syar'I, Sumber: https://republika.co.id/berita/koran/news-update/nx65s74/hukuman-kebiri-dalam-tinjauan-syari, diakses Rabu, 1April 2020.
} 
hukum Islam. Ia menyebutkan bahwa dalam Al Qur`an secara tegas dan jelas menyatakan mengenai dibolehkannya hukum mati termasuk kebiri terhadap pembunuh, pemerkosa. ${ }^{43}$ Bahkan menurutnya lagi bahwa lebih dari kebiri, alQur`an membolehkan seperti potong tangan dan kaki sebagaimana termaktub dalam firman Allah SWT.:

"Sesungguhnya pembalasan terhadap orang-orang yang memerangi Allah dan rasul-Nya dan membuat kerusakan di muka bumi, hanyalah mereka dibunuh atau disalib, atau dipotong tangan dan kaki mereka dengan bertimbal balik, atau dibuang dari negeri (tempat kediamannya). Yang demikian itu (sebagai) suatu penghinaan untuk mereka didunia, dan di akhirat mereka beroleh siksaan yang besar”. (QS. al-Maidah: 33).

Ketika memperhatikan dan mengamati secara seksama penjelasan sekaligus alasan/dalil yang digunakan kedua pernyataan yang membolehkan pemberian hukuman kebiri pada terpidana pedofilia, penulis berpandangan bahwa sesungguhnya pembolehan tersebut menyalahi aturan nash yang ada. Seperti yang telah disinggung bahwa seorang mujtahid termasuk di dalamnya kepala negara tidak boleh melakukan ijtihad pada hal-hal yang telah ada nasnya secara jelas.

Selain itu, pernyataan yang membolehkan adanya hukuman kebiri tentu saja di sisi lain memunculkan pertanyaan baru yakni, bagaimana jika seandainya pelaku kejahatan seksual terhadap anak di bawah umur justru seorang perempuan, dan bukan laki-laki? Kalau dikatakan boleh hukuman kebiri, apanya perempuan itu yang dikebiri; dan bagaimana caranya? Ini semua akan menjadi masalah karena dalam konteks sekarang, bukan hanya laki-laki yang melakukan kejahatan seksual terhadap anak, tetapi juga perempuan sangat berpotensi melakukan hal yang sama.

Terhadap kondisi seperti ini, para ulama fiqh telah meletakkan beberapa kaedah yang berkenaan dengan masalah ini, antara lain:

\footnotetext{
${ }^{43}$ Lihat Jakarta (Pos Kota), Kamis (26/5/2016). Diakses pada tanggal 17 September 2019.
} 


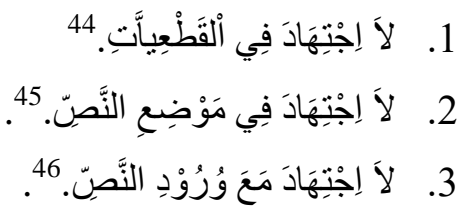

1. Tidak boleh berijtihad dalam masalah yang hukumnya sudah pasti.

2. Tidak boleh berijtihad dalam masalah yang ada nashnya.

3. Tidak boleh berijtihad bila ada nash.

Maksud daripada peniadaan ijtihad dalam kaedah di atas adalah ketika ada nash, yakni jika nash tersebut sahih dan sangat jelas. Berbeda jika ijtihad dilakukan karena ingin memahami nash dengan tujuan mengaplikasikannya dalam kehidupan nyata maka hal itu boleh saja dilakukan dengan syarat nashnya adalah zanniyu addilalah (belum jelas maksud yang sesungguhnya) karena hal tersebut dianggap sebagai ijtihad yang dilakukan untuk memahami nash. ${ }^{47} \mathrm{Jadi}$, dalam suatu masalah yang hukumnya sudah pasti (maqtu') yakni yang ditetapkan berdasarkan ijma' para ulama maka hukumnya tidak dapat diotak-atik lagi dan akan menjadi ketetapan untuk selamanya seperti halnya wajibnya shalat, puasa, zakat, dan haji, haramnya mencuri, berzina, dan meminum minuman keras, termasuk dalam hal ini adalah tidak bolehnya hukuman kebiri. ${ }^{48}$

Ketika ulama sudah sepakat bahwa kebiri pada manusia hukumnya haram, ${ }^{49}$ maka tentu saja dapat dipahami bahwa suatu hukum yang disimpulkan berdasarkan konvensi para ulama (ijma' para ulama) tidak akan mungkin mengalami perobahan karena ijma' sendiri jauh lebih kuat dari pada suatu hukum yang ditetapkan hanya berdasarkan dalil semata. Para ulama usul mengatakan bahwa seorang yang ingin melakukan ijtihad ia terlebih dahulu harus mengetahui semua permasalahan yang telah disepakati sebelumnya (al-masail al-mujma' alaihi) sehingga dalam proses pengistimbatan hukum tidak terjadi kontradiksi

\footnotetext{
${ }^{44}$ Muhammad bin Ali Assyakani, Irsyadu al-Fuhul Ila Tahkiki al-Hakki min Ilmi al-Usul, Dar al-Kitab al-Arabiy, Kairo, Jld.2.hal.206.

45 Abdullah bin Yusuf al-Judaiy, Taisir Ilmi Usul al-Fikhi, Maktabah Syamilah, Jld.3.hal.92.

${ }^{46}$ Amir bin Isa, Daur al-Ijtihad fi Tagyiri al-Fatwa, Maktabah Assyamilah, hal.4.

${ }^{47}$ Ibid, hal.4.

${ }^{48}$ Abdullah bin Yusuf al-Judaiy, Opcit, hal.92.

${ }^{49}$ Al-Mausuah al-Fiqhiyah al-Kuwaitiyah, 1427 H, Wizarah al-Auqaf wa Assyu'uni alIslamiyah, Kuwait, Jld.40.hal.261
} 
dengan ijama' yang telah ada. Karenanya, bila seorang mujtahid tidak mengetahui persoalan hukum yang telah disepakati, lalu ia berijtihad dalam masalah yang sama dan menghasilkan konklusi hukum yang berbeda dengan yang pertama maka ijtihad tersebut dianggap sebagai sesuatu yang tidak berarti. ${ }^{50}$ Jadi, suatu hukum agama yang ditetapkan berdasarkan ijma' para ulama sifatnya qat'iy. Artinya hukum tersebut wajib diaplikasikan dalam bentuk nyata dan tidak boleh diabaikan. Atau dengan kata lain, hukum tersebut wajib diikuti dan tidak diperbolehkan kepada siapa pun setelah itu mempersoalkannya kembali atau ingin melahirkan satu gagasan baru dalam persoalan yang sama sekalipun dengan melakukan ijtihad. ${ }^{51}$ Hukuman yang diberlakukan sekalipun atas nama maslahat tetapi kalau menyalahi nash agama maka dianggap tidak sah atau batal.

Adapun ayat al-Qur'an surat al-Maidah ayat 33 yang disebutkan sebagai dalil bagi yang membolehkan hukuman kebiri, sesungguhnya konteksnya adalah berbicara mengenai hukum hirabah yang memang membolehkan penjatuhan hukuman mati atas pelaku kejahatan itu. Ayat tersebut sama sekali tidak berbicara tentang hukuman kebiri, sehingga dapat disimpulkan bahwa bila ayat tersebut dikaitkan dengan hukum kebiri maka tentu akan keluar dari konteks ayat yang sesungguhnya. Itulah sebabnya mengapa dalam kitab-kitab turats, ulama sepakat mengharamkan kebiri untuk manusia seperti yang telah disinggung.

Selain ulama klasik, mereka yang yang tidak setuju dengan hukuman kebiri juga berasal dari beberapa organisasi; dan dari kalangan kontemporer, seperti Majelis Tarjih dan Tajdid PP Muhammadiyah, Asosiasi Pondok Pesantren Jawa Timur, serta kalangan ulama kontemporer lainnya. Mereka berdalil, kebiri berarti mengubah fisik manusia, melanggar HAM, dan melahirkan jenis hukum baru yang tidak pernah dikenal dalam konsep jinayah Islamiyah atau hukum pidana Islam. ${ }^{52}$ Kebiri secara kimiawi tidak dibenarkan oleh syariat Islam sebagai hukuman alternatif bagi tindak kejahatan seksual karena berdampak berubahnya

${ }^{50}$ Wahbah Azzuhaili,1986, Usul Fiqh al-Islamiy, Dar al-Fikr, Beirut, hal.497

51 Abdul Fattah Husain Syeh, Dirasat fi Usul al-Fikhi, Universitas al-Azhar, Kaior, hal.179.

52 Republika.co.id, Bolehka hukum kebiri dalam syariat Islam, Sumber: https://www.republika.co.id/berita /dunia-islam/islam-nusantara/15/10/30/nx179u313-bolehkahhukum-kebiri-dalam-syariat-islam, diakses, Jumat, 13 Maret 2020 
hormon testosteron menjadi hormon estrogen. Akibatnya, laki-laki yang mendapatkan hukuman ini akan berubah dan memiliki ciri-ciri fisik seperti perempuan. ${ }^{53}$ Tentu saja, seorang laki-laki yang menyerupai perempuan atau sebaliknya hukumnya haram sebagaimana sabda Nabi saw dari Ibnu Abbas: "Rasulullah SAW telah melaknat laki-laki yang menyerupai wanita, dan melaknat wanita yang menyerupai laki-laki". 54 Jika laki-laki yang menyerupai wanita diharamkan, maka wasilah yang menjadikan keharaman ini terlaksana juga diharamkan. Kaidah fiqh mengatakan:

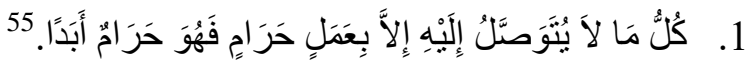

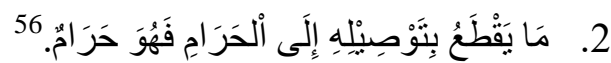

1. Segala sesuatu yang tidak mungkin dapat dicapai kecuali melakukan sesuatu yang haram maka juga hukumnya haram untuk selamanya.

2. Sesuatu yang dipastikan mengakibatkan kepada sesuatu yang haram maka hukumnya juga haram.

Selain alasan di atas, kebiri kimia menurut para ahli mempunyai dampak negatif termasuk mempercepat penuaan tubuh. Selain itu, cairan antiandrogen yang disuntikkan ke dalam tubuh mengurangi kerapatan massa tulang sehingga tulang keropos dan memperbesar resiko patah tulang. Obat itu juga mengurangi massa otot dan meningkatkan lemak yang menaikkan resiko penyakit jantung dan pembuluh darah. Jika pemberian antiandrogen dihentikan, dorongan seksual dan fungsi ereksi seseorang akan muncul lagi.

Dengan demikian kebiri kimiawi tidak bersifat permanen, namun sementara saja. Kebiri kimia tidak menyembuhkan perilaku penjahat seksual karena saat masa hukuman selesai, pelaku masih bisa mengulangi kejahatannya jika pemicunya melakukan kejahatan seksual tidak ditangani. ${ }^{57}$ Selain itu, Ketua

\footnotetext{
${ }^{53}$ Republika.co.Id, Ibid,

${ }^{54}$ Hadis riwayat Bukhari, Opcit,.hal.2207.

${ }^{55}$ Ibnu Hazm, al-Ihkam Fi Usuli al-Ahkam, Dar al-Hadis, Kairo, jld.3.hal.320.

${ }^{56}$ Tajuddin Assubkiy, 1991, al-Asybah wa Annazair, Dar al-Kutub al-Ilmiyyah, Bairut, jld.1.hal.136.

57 Kompas.com, Suntik Kebiri untuk Mematikan Dorongan Seksual, Sumber: https://ekonomi.kompas.com/
} 
Perhimpunan Dokter Spesialis Andrologi, Prof. DR. dr. Wimpie Pangkahila, MSc, Sp.And mengatakan pemberian obat kebiri kimia tidak menjamin seorang pelaku kekerasan seksual akan jera. Kebiri kimia adalah memberikan obat antitestosteron secara beberapa kali. Apa yang terjadi? Level testosteronnya makin berkurang, gairah seksualnya hilang, dan kemampuan ereksi terganggu. Menurut Wimpie, kalau suntikan dihentikan, libido dan ereksinya bisa kembali lagi. Bahkan menurutnya, tidak pernah ada laporan yang menyebutkan pemberian obat kebiri kimia akan membuat pelaku kekerasan seksual menjadi jerah. Gairah seksualnya mungkin hilang. Tapi keinginan untuk mengulangi perbuatannya dulu kan masih ada. Terlepas apakah fungsi seksualnya masih mampu atau tidak, tutupnya. ${ }^{58}$

Berdasar pada penjelasan di atas dapat disimpulkan bahwa seorang kepala negara tidak boleh mengambil suatu kebijakan yang bersifat menafikan bila syariat Islam justru menetapkannya sebagai sesuatu yang harus dilaksanakan. Sebaliknya, seorang presiden dalam mengambil kebijakan tidak boleh memberlakukan hal-hal yang justru dilarang oleh agama sekalipun atas nama kemanusian. ${ }^{59}$ Penjatuhan hukuman kebiri atas pelaku kejahatan seksual tidak boleh dilaksanakan karena dianggap menyalahi aturan agama seperti yang telah dijelaskan panjang lebar. Pertanyaannya kemudian adalah apakah boleh menjatuhkan hukuman mati atas pelaku kekerasan seksual? Apalagi jika hukuman mati dijadikan sebagai bagian dari hukuman ta'zir. Seperti yang dijelaskan para ulama bahwa ta'zir adalah hukuman yang tidak ditentukan kadarnya/jumlahnya, dan wajib dilaksanakan sebagai hak Allah atau hak manusia dalam setiap maksiat yang hukumannya tidak ada di dalamnya had atau kaffarah. ${ }^{60}$ Adapun sisi perbedaan antara had dengan ta'zir seperti yang dijelaskan al-Mawardi adalah bahwa hukuman yang bersifat had tidak boleh dibatalkan/dimaafkan, sementara

$\mathrm{read} / 2014 / 05 / 19 / 1659515 /$ Suntik.Kebiri.untuk.Mematikan.Dorongan.Seksual?page=all, diakses 3 April 2020.

58 Bbc.com, Jaksa Agung Tegaskan Hukuman Kebiri Diatur UU, Sumber : https://www.bbc.com/ indonesia/berita_indonesia/2016/06/160613_indonesia_kebiri_idi_dokter. diakses Kamis, 2 April 2020.

59 Yusuf Qardawi, 1998, al-Siyasal al-Syar'iyyah fi Dau'i Nusus Assyari'ah alIslamiyah, Maktabah Wahbah, Kairo, hal.106.

${ }^{60}$ Kamal Ibnu al-Humam, Opcit. hal.211. 
hukuman ta'zir dapat dibatalkan/dimaafkan. ${ }^{61}$ Karena ta'zir merupakan satu bentuk hukuman maka syariat Islam tidak mewajibkannya kecuali atas orangorang yang sudah mukallaf sehingga bila seorang mukallaf melakukan satu pelanggaran dosa yang tidak ada hukumannya secara pasti (had) maka ia bisa dihukum ta' $^{\prime}$ ir. $^{62}$

Sebab hukuman ta'zir tidak ditentukan kadar dan macamnya secara detail oleh syariat Islam, agar pemerintah dalam hal ini dapat melakukan pengkondisian hukuman itu sendiri sehingga maksud dan tujuan pemberlakuan hukuman ta'zir dapat dilaksanakan secara maksimal sehingga pencegahan kejahatan dapat diminimalisir. Selain itu, sebagian ulama fiqh membolehkan penyatuan hukuman ta'zir dengan had dalam setiap perbuatan tindak pidana seperti yang dikatakan ulama Hanafiyah. ${ }^{63}$ Alasan mereka adalah bahwa memang betul kalau setiap tindakan kejahatan yang hukumannya sudah jelas (had) tidak perlu lagi ada ta'zir karena sudah dianggap cukup. Tetapi pada dasarnya tidak ada alasan untuk melarang menyatukan ta'zir dengan had jika kondisi menuntut penyatuan tersebut dengan pertimbangan maslahat seperti menghukum ta'zir pelaku kejahatan yang menyebabkan orang lain cacat fisik di samping menghukum kisas mereka. ${ }^{64}$

Hal yang sama juga dijelaskan dalam mazhab Syafi'i tentang bolehnya penyatuan hukuman had dengan ta'zir seperti menambah 40 kali cambuk bagi peminum khamar; dan kalau lebih 40 kali jumlahnya maka tambahan tersebut adalah ta'zir. Jika melihat pernyataan tersebut, muncul pertanyaan yakni apakah seorang kepala negara boleh menghukum ta'zir seorang pelaku kejahatan seksual dengan hukuman mati? Nampaknya sebagian ulama fiqh merespon hal tersebut, sebut saja misalnya Abu Hanifah melihat bahwa boleh saja seorang pelaku tindak pidana dijatuhi hukuman ta'zir dengan ancaman hukuman mati jika pelaku tersebut telah berulangkali melakukan kejahatannya; dan kejahatan tersebut memang masuk dalam kategori pelakunya dapat dibunuh. Misalnya seorang sudah

${ }^{61}$ Al-Mawardi, al-Ahkam Assultaniah, hal.237.

62 Addasuki, Hasyiah Addasuki Ala Syarhi al-Kabir, Matba'ah al-Amiriyah, Kairo, Jld.4.hal.354.

${ }^{63}$ Kamal Ibnu al-Humam, Opcit, hal.135. Kairo, Jld.6.hal.267.

${ }^{64}$ Al-Hattab, Mawahibu al-Jalil Syarhu Mukhtasar al-Khalil, Matba'ah Assa'adah, 
berulang kali telah melakukan homo seksual (liwat), atau membunuh seseorang karena ingin mengambil hartanya. Alasannya sangat sederhana. Mereka mengatakan: "Suatu kejahatan yang tidak ada putus-putusnya, dan selalu terjadi, kalau saja untuk memberhentikannya hanya dengan cara membunuhnya maka pelaku kejahatan tersebut dibunuh". 65

\section{Penutup}

Berdasar pada penjelasan di atas, dapat disimpulkan beberapa hal sebagai berikut: (i) Para ulama menyatakan bahwa haram hukumnya menerapkan hukum kebiri untuk pelaku pedofilia, karena syariat Islam sudah menetapkan rincian hukuman tertentu bagi pelaku pedofilia. Kebiri berarti mengubah fisik manusia. Syariat Islam tidak membenarkan kebiri secara kimiawi sebagai hukuman alternatif bagi tindak kejahatan seksual karena berdampak berubahnya hormon testosteron menjadi hormon estrogen. Akibatnya, laki-laki yang mendapatkan hukuman ini akan berubah dan memiliki ciri-ciri fisik seperti perempuan. Selain itu, kebiri kimia menurut para ahli mempunyai dampak negatif termasuk mempercepat penuaan tubuh. Cairan antiandrogen yang disuntikkan ke dalam tubuh mengurangi kerapatan massa tulang sehingga tulang keropos dan memperbesar resiko patah tulang. Obat itu juga mengurangi massa otot dan meningkatkan lemak yang menaikkan resiko penyakit jantung dan pembuluh darah. (ii) Boleh bagi seorang kepala negara memaafkan orang yang melakukan pelanggaran bila hukumannya hanya sebatas ta'zir. Atau dengan kata lain, kepala negara dibenarkan memberlakukan amnesti ta'zir, sebagaimana ia boleh menyatukan hukuman had dengan ta'zir dalam semua tindak kejahatan seperti yang dikatakan mazhab Hanafiyah dan mazhab Syafi'iyah. (iii)Jika kasus yang sedang dibicarakan dikaitkan dengan masalah ta'zir maka dapat disimpulkan bahwa seorang pelaku kejahatan seksual dapat dijatuhi hukuman mati jika ia memerkosa lalu membunuh korban. Hukuman mati yang dijatuhkan atas pelaku kejahatan tersebut bukan karena ia memerkosa, tetapi karena ia membunuh; dan

${ }^{65}$ Ibnu Taimiyah, Assiyasah Assyar'iyyah, hal.102. Lihat juga Ibnu Farhun, Tabsiratu alHukkam, Maktabah al-Kulliyah al-Azhariyah, Kairo, Jld.2.hal.297. 
tentunya pembunuhan itu dilakukan secara sengaja atau al-katlu al-amdu. (iv) Abu Hanifah melihat bahwa pelaku kejahatan seksual dapat dita'zir dengan hukuman mati oleh kepala negara jika kejahatan tersebut dilakukan berulangkali. Alasannya adalah bahwa suatu tindak kejahatan yang tidak ada putus-putusnya, dan selalu terjadi, kalau saja untuk memberhentikannya hanya dengan cara membunuh pelaku maka boleh dibunuh.

\section{Daftar Pustaka}

Abu Jieb, Sa'diy, al-Qamus al-Fikhiy, Dar al-fikri, Dimask.

Addasuki, Hasyiah Addasuki Ala Syarhi al-Kabir, Matba'ah al-Amiriya, Kairo.

Al-Baihaqi, 1410 H, Syuabu al-Iman, Dar al-Kutub al-Ilmiyah, Beirut

Al-Buhutiy, Kassyaf al-Qina, Matba'ah al-Syarafiyah, Kairo.

Al-Hattab, Mawahibu al-Jalil Syarhu Mukhtasar al-Khalil, Matba'ah Assa'adah, Kairo.

Al-Jauziyah, Ibnu Qayyim, I'lam al-Muwaqqiin, Dar al-Hadis, Kairo.

Al-Juadaiy, Abdullah bin Yusuf al-Judaiy, Taisir Ilmi Usul al-Fikhi, Maktabah Syamilah.

Al-Mawardi, Abu al-Hasan, al-Ahkam al-Sulthaniyah, Dar al-Fikr, Beirut.

Al-Mausuah al-Fiqhiyah al-Kuwaitiyah, 1427 H, Wizarah al-Auqaf wa Assyu'uni al-Islamiyah, Kuwait.

Assadr, Mahmud bin Ahmad, al-Muhit al-Burhaniy, Dar Ihya Atturats al-Arabiy, Kairo.

Assubkiy, Tajuddin, 1991, al-Asybah wa Annazair, Dar al-Kutub al-Ilmiyyah, Beirut.

Assyaukani, Muhammad bin Ali, Irsyadu al-Fuhul Ila Tahkiki al-Hakki min Ilmi al-Usul, Dar al-Kitab al-Arabiy, Kairo.

Azzuhaili, Wahbah, 1986, Usul Fiqh al-Islamiy, Dar al-Fikr, Beirut.

Bukhari, 1987, Sahih Bukhari, Dar Ibni Katsir, Beirut.

Ibnu al-Humam, Kamal, al-Hidayah Ma'ah Fathil al-Qadir, Matba'ah Mustafa Muhammad, Kairo

Ibnu Farhun, Tabsiratu al-Hukkam, Maktabah al-Kulliyah al-Azhariyah, Kairo.

Ibnu Hazm, al-Ihkam Fi Usuli al-Ahkam, Dar al-Hadis, Kairo.

Isa, Amir bin , Daur al-Ijtihad fi Tagyiri al-Fatwa, Maktabah Assyamilah.

Mahmasani, Subhi, 1980, Falsafatu Attasyri' fi al-Islam, Dar Ilmi Lilmalayin, Beirut.

Qardawi, Yusuf,1998, Al-Siyasah al-Syar'iyyah, Maktabah Wahbah, Kairo. Igatsah Allahfan, (t.t).

Syeh, Abdul Fattah Husain, Dirasat fi Usul al-Fikhi, Universitas al-Azhar, Kairo.

Jurnal/ Artikel

Noviana, Ivo. "Kekerasan seksual terhadap anak: dampak dan penanganannya." Sosio Informa 1, no. 1 (2015). 
Eddyono, S. W.et.al (2016). Menguji euforia kebiri: Catatan kritis atas rencana kebijakan Kebiri (chemical castration) bagi pelaku kejahatan seksual anak di Indonesia. Jakarta: Institute for Criminal Justice Reform (ECPAT) Indonesia.

\section{Website}

Bbc.com, Jaksa Agung Tegaskan Hukuman Kebiri Diatur UU, Sumber : https://www.bbc.com/ indonesia/berita_indonesia/2016/06/160613_indonesia_kebiri_idi_dokter. diakses Kamis, 2 April 2020.

DetikNews.com, Jalan Panjang Pembunuhan Sadis Eno yang Berujung Hukuman Mati, Sumber : https://news.detik.com/berita/d-3417513/jalan-panjangpembunuhan-sadis-eno-yang-berujung-vonis-mati?_ga=2 .201689233.1240205547.1583897755-888393700.1572396624. Diakses 11 Maret 2020.

, Korban Kekerasan Seksual yang Menjadi Pelaku Kala Dewasa, Sumber : https://news.detik.com/berita/d-2572489/korban-kekerasanseksual-yang-menjadi-pelaku-kala-dewasa/8. Diakses, Kamis, 2 April 2020.

Hukumonline, Menkumham Kaji Wacana Hukuman Kebiri Pelaku Pedofi, Sumber

https://www.hukumonline.com/berita/baca/lt5628ee32df202/menkumhamkaji-wacana-hukuman-kebiri-pelaku-pedofil, diakses Ahad, tanggal 22 Maret 2020.

Komnasperempuan.go.id, Lembar Fakta Catahu 2018, Sumber: https://www.komnasperempuan.go.id/file/pdf_file/2018/SIARAN\%20PER S\%202018/Lembar\%20Fakta\%20Catahu\%207\%20Maret\%202018.pdf. Diakses, Ahad 22 Maret 2020.

Kompas.com, Suntik Kebiri untuk Mematikan Dorongan Seksual, Sumber: https://ekonomi.kompas.com/ read/2014/05/19/1659515/Suntik.Kebiri.untuk.Mematikan.Dorongan.Seks ual?page=all, diakses Jumat, 3 April 2020.

Kumparan.com, 12 Kasus Pedofilia di Indonesia, sumber: https://kumparan.com/kumparannews/12-kasus-pedofilia-di-indonesia, diakses Rabu, 25 Maret 2020.

Kpai.go.id, Rincian Data Kasus Berdasarkan Klaster Perlindungan Anak, Sumber : https://bankdata.kpai.go.id/tabulasi-data/data-kasus-per-tahun/rinciandata-kasus-berdasarkan-klaster-perlindungan-anak-2011-2016, diakses Rabu, 1 April 2020.

Liputan6.com, Kronologi Kasus Kematian Yuyun di Tangan 14 ABG Bengkul. Sumber: https://www.liputan6.com/regional/read/2499720/kronologikasus-kematian-yuyun-di-tangan-14-abg-bengkulu, diakses Rabu, 11 Maret 2020.

Republika.co.id, Bolehka hukum kebiri dalam syariat Islam, Sumber: https://www.republika.co.id/berita /dunia-islam/islamnusantara/15/10/30/nx179u313-bolehkah-hukum-kebiri-dalam-syariatislam, diakses, Jumat, 13 Maret 2020. 
Hukuman Kebiri dalam Tinjauan Syar'I, Sumber: https://republika.co.id/berita/koran/news-update/nx65s74/hukuman-kebiridalam-tinjauan-syari, diakses Rabu, 1April 2020.

Tempo.Co. Surga Pedofilia Bernama Nusantara, Sumber https://majalah.tempo.co/read/laporan-utama/ 145293/surga-pedofiliabernama-nusantara?hidden=login,diakses Rabu, 25 Maret 2020

Tribunnews.com, Robert Ellis Dihukum 15 Tahun Penjara di Bali, Sumber: https://www.tribunnews.com/australia-plus/2016/10/26/robert-ellisdihukum-15-tahun-penjara-di-bali. diakses, Kamis, 26 Maret 2020

\section{Peraturan Perundang-Undangan}

Undang-Undang Dasar 1945 Negara Kesatuan Republik Indonesia.

Undang-Undang No. 21 Tahun 2007 Tentang Pemberantasan Tindak Pidana Perdagangan Orang (Lembaran Negara Republik Indonesia Tahun 2007 Nomor 58, Tambahan Lembaran Negara Republik Indonesia Nomor 4720).

Undang-Undang No. 35 Tahun 2014 Tentang Perubahan Atas Undang-Undang No. 23 Tahun 2002 Tentang Perlindungan Anak (Lembaran Negara Republik Indonesia Tahun 2014 Nomor 297, Tambahan Lembaran Negara Republik Indonesia Nomor 5606).

Peraturan Pemerintah Pengganti Undang-Undang (Perpu) Nomor 1 Tahun 2016 Tentang Perubahan Kedua Atas Undang-Undang No. 23 Tahun 2002 Tentang Perlindungan Anak (Lembaran Negara Republik Indonesia Tahun 2016 Nomor 99, Tambahan Lembaran Negara Republik Indonesia Nomor 5882).

\section{Dokumen Lainnya}

RUU Penghapusan Kekerasan Seksual, versi DPR RI, Sumber: https://www.dpr.go.id /doksileg/proses2/RJ2-20170201-043128-3029.pdf. Diakses Kamis, 26 Maret 2020 